\title{
Seguridad Alimentaria: Juégatela seguro con los huevos $^{1}$
}

\author{
Linda B. Bobroff y Jennifer Hillan²
}

Los huevos frescos pueden contener bacterias que podrían causar una enfermedad llamada salmonelosis. Esta enfermedad causada por alimentos provoca vómito y diarrea. Esta puede ser severa y hasta podría ser fatal para los adultos mayores. Reduzca el riesgo de contraer estas enfermedades causadas por sequir estas pautas.

\section{Use el huevo de una manera}

\section{segura}

- No compre huevos quebrados.

- Compre huevos antes de la fecha de vencimiento en el cartón y úselos en las próximas 3 a 5 semanas.

- Refrigere los huevos frescos después de comprarlos. Manténgalos en el cartón original en la parte más fría del refrigerador.

- Cocine los huevos hasta que la yema y la clara estén firmes. Los huevos revueltos no deben moverse.

- Cocine las cacerolas y otros platos a $160^{\circ} \mathrm{F}$.
- No come comidas hechas con huevos crudos o poco cocidos, tales como nieve o helado hecho en casa, aderezo de ensalada César o salsa holandesa; pueden enfermarle. Se puede usar huevos previamente pasteurizados en algunas recetas que piden huevos crudos, para asegurar la seguridad del plato.

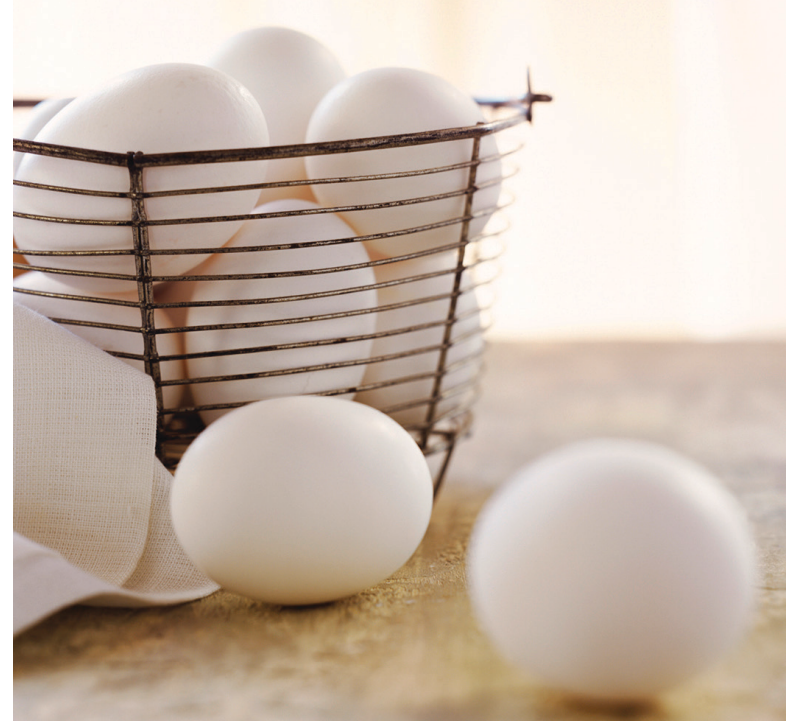

Figura 1. Compre huevos antes de la fecha en el envase. Guarde en la caja de cartón en la parte más fría del refrigerador por no más de 5 semanas. Créditos: Digital Vision

1. The English version of this document is Food Safety: Play it Safe with Eggs (FCS8635). Este documento es FCS8635-Span, uno de una serie del Departamento de Ciencias de la Familia, la Juventud y la Comunidad, UF/IFAS Extensión. Publicado: mayo 2010. Revisado: octubre 2013. Traducido del Inglés por Rafael Arango y Claudia Peñuela. Por favor visite el sitio en la web en EDIS http:// edis.ifas.ufl.edu.

2. Linda B. Bobroff, PhD, RD, LD/N, profesora, Departamento de Ciencias de la Familia, la Juventud y la Comunidad, y Jennifer Hillan, MSH, RD, LD/N, anterior educadora de nutrición ENAFS; UF/IFAS Extensión, Gainesville, FL 32611. 


\section{¿Y qué tal las sobras?}

- Use los huevos cocidos en menos de una semana después de haberlos cocido.

- Refrigere inmediatemente las sobras de platos con huevo y úselos en menos de 3 días.

- Recaliente las sobras de platos con huevo a $165^{\circ} \mathrm{F}$ antes de consumirlas. 